\title{
The Cultural and Social Interaction between Chinese Muslim Minorities and Chinese Non-Muslim Majority in China: A Sociological Analysis
}

\author{
Osman Abdullah Chuah ${ }^{1}$ \\ ${ }^{1}$ Department of Usuluddin and Comparative Religion, International Islamic University Malaysia, Selangor, \\ Malaysia \\ Correspondence: Osman Abdullah Chuah, Department of Usuluddin and Comparative Religion, International \\ Islamic University Malaysia, Jalan Gombak, 53100, Gombak, Selangor, Malaysia. Tel: 60-17-889-2448. E-mail: \\ ochuah1948@yahoo.com; ochuah@iium.edu.my
}

Received: July 31, 2012 Accepted: September 5, 2012 Online Published: November 30, 2012

doi:10.5539/ass.v8n15p267

URL: http://dx.doi.org/10.5539/ass.v8n15p267

\begin{abstract}
The paper is a research on the interaction between Chinese Muslim minority, the Hui with the non-Muslim majority, the Han in China. The findings prove that the Hui in China remain a marginalized group with little influence on political, economical, cultural and social affairs. It is also confirmed that for the Hui people, Islam is practised as a comprehensive way of life unlike the Chinese non-Muslims. In China, the non-Muslim majority, the Han recognize the Hui people only as a minority ethnic group. There are three kinds of relationship between the Muslim Hui and the non-Muslim Han. First, there is peaceful co-existence between the non-Muslim Han and Muslim Hui, the latter resisting the great force of assimilation and acculturation of non-Muslim ways. Second, there is intensification and persecution of the Hui by the Han. Third, the Hui cannot take the pressure of intensified prejudice, persecution and discrimination and so they revolt against the Han. These three kinds of relationship continue to exist in China depending on the delicate and complex situation between the non-Muslim Han and the Muslim Hui in China.
\end{abstract}

Keywords: Chinese Muslim minorities, Chinese Non-Muslim majority, cultural and social interaction, sociological analysis

\section{Introduction}

The Chinese Muslims in China are known as the Hui people. They belong to the biggest Muslim ethnic group of all Muslim tribes in China. Hui also refers to the Muslim community. The Hui share the same language, culture and social way of life with the non-Muslim Han but unlike the Han, the Hui are also part of the world wide Muslim ummah. The faith and practice of Islam also make the Hui different from the non-Muslim Han. Because of these differences, conflicts, mutual prejudices, discriminations and stereotypes are part of the norms between the Hui and the Han. The Hui do not belong to a majority group; the population is concentrated in North West China and dispersed in the remaining parts of China. There is also substantial acculturation and assimilation of the Hui towards the Han in China in their social interaction.

\subsection{The Hui Min and the Difference between the Hui and the Han}

Uniquely different from the rest of the Muslims in the world, the Chinese Muslims or Hui in China are also known as Hui Min, literally known as the tribe of Hui. This terminology is not in Al-Quran. It is however spoken in the daily usage of the Chinese, among the Hui or the Han. According to a Chinese scholar who visited Malaysia, the Chinese word 'hui' has two squares. The inner square refers to the Ka'bah and the outer square refers to the universality of Islam (Note 1). The word 'hui' also means "return to" in Chinese and hence, it means the religion of Hui is to return to Allah. 'Hui' also refers to the tribal groups in the North West of China like Sinkiang, namely Uighur, Kazath, Kirghiz, Uzbek, and Tatar. There is also Persian speaking Tadjik there. Although all Hui are Muslims, not all Muslims are Hui or from the tribal groups mentioned as there are also non-Muslim Han who converted to Islam and are known as Han Hui. To embrace Islam is also known as to enter into the Hui way in China. For the sake of this study, Hui refers to the Muslims and Han refers to the non-Muslims in China. 
The word 'Han' refers to the dominant Chinese non-Muslims although some of them had embraced Islam. Their children are known as Han Hui. In China, the mosque too is known as Hui Min Si or Ching Cheng Si. Islam is also known as Ching Cheng Chiaw (the true and pure religion). A halal restaurant is also known as Ching Cheng Chan Kuan (clean and pure restaurant).

The cultural and social differences between the Hui and the Han or between Islam and the Chinese non-Muslim ways frequently create suspicion and distrust between the two communities. Although the Hui speak the same Chinese language or Mandarin in schools, the Han do not fully accept the Hui as Chinese but only as a minority group. Because of this, there are three kinds of relationship between the Hui and the Han. These are the relationship between the two groups of communities: the minority and the majority, the dominant and the dominated, and the strong and the weak.

\section{Methodology of Research}

The most important concepts used in this research is the majority group, minority group and assimilation. Majority group and minority group are opposite in term of meanings. Here it is not referring to the numerical number of Han and Hui but the controlling political power and the marginalised power respectively. At one time, in the apartheid of South Africa, the black were numerically larger in number compared with the white but it is the white as the majority group as it was the political power deciding any policy but the black was the marginalised with no power. Thus the black was the minority group. In the similar situation, the Hui has no political power in China and the Han is like white men in the apartheid with political power. With power, the Han could decide policy of education like the uses of language as a medium of Mandarin for all schools and universities. Thus the Hui would be deprived of the practice of using the local language and even the use of Arabic language in Al-Quran. In term of language, the hui would be assimilated into the han linguistically in the long run.

Thus, in the long run, a minority group can lose his identity by the act of governmental policy. Another policy of the government by the Han is population transfer. That is in the concentrated area of minority group like Tibet, massive number of han have been transferred into Tibet. This would make the Tibetan less in numerical number compared with the Han in the home of Tibatan. This also resulted in the loss of economic vacancies and opportunities for the Tibetan as more Han competing in Tibet. Thus protest and even self-immolation by Tibatan were known by researchers of minority affairs (Note 2). Tibatan is one of the minority people in China officially recognised by the Han government. Similarly the Hui in Sinkiang and North West of China are sharing the same experience of population transfer by the han. A survey is done among the students of hui coming to study in Malaysia. The hui was the majority in number in the past in North East China but it is now only $50 \%$, the remaining $50 \%$ are han (Note 3 ). The only difference compared the hui with the Tibatan is that self-immolation is forbidden by the teaching of Islam. Thus no hui had done it but other forms of responses by the hui community thus exist.

By assimilation in this study, it refers to the loss of ethnic identity of the minority group and absorbed into the way and culture of majority group (Note 4). Maintaining self-identity of hui is important for the hui survival. It is not easy to resist assimilation to the han way. Governmental policies want to maintain national identities. Han culture is given priority for instance. For example, in some part of China, the hui students are not allowed to fast in the month of fasting recently (Note 5). This is the way to make young hui children to gradually lose confidence in the way of hui and prepared for future assimilation to the way of han.

\section{Peaceful Co-existence between the Hui and the Han}

Peaceful co-existence between the two communities, the Hui and the Han is one of the relations between the two ethnic groups in China. However, each community is confident of its superiority and both sides avoid direct conflict. The Hui as the smaller community of the two is the dominated and weak group, numerically small compared to the Han. It is constantly diffused with the culture of the non-Muslim Han. There are two pressures on the Hui; the pressure that pushes them to acculturate and assimilate into the non-Islamic ways and the pressure to maintain and preserve the Islamic activities, culture and identity. As long as the two types of pressure are within tolerable levels, the Hui and the Han can co-exist peacefully in a normal situation.

The pressure of assimilation in China is from the han government. First, the official education system in the country does not cater to the Islamic system and values. Although there are Islamic schools or al-madrasah in China, these are few and located far away from many Muslims. Basic Arabic and Islam are taught in madrasah, mosques and universities; nothing at the advanced levels. Most of the Muslim children have to go to normal Chinese schools where Islamic education is not in the curriculum. Mandarin is the common language and official medium of all schools and universities in China where Hui, Han and other Chinese children attend. 
Furthermore, the attires of the Hui and Han are not much different. On the outside, mosques in China resemble Chinese temples. Most of the institutions do not cater to the needs of Muslim requirements. For example, military training does not provide halal food for the Muslim student cadets. In addition, certain Muslim scholars apologetically present the similarities between Islam and Confucianism in China. This is to ease the external pressure against the Hui from the social forces of the non-Muslim Han.

The external pressures and social interaction generate strong internal pressure for Islamic identity. Thus, the Hui call themselves by their Islamic names, greet each other in Islam, put on their special attire for prayers before facing the Qibla and go for pilgrimage in Makkah if they are financially capable (Note 6). There is a peaceful yet uneasy co-existence between the Hui and the Han in China. Even to work in the government requires the passing of an examination based on the non-Islamic Chinese syllabus. This takes place usually at the setting in which the majority of the people are Chinese non-Muslim Han but the Muslim Hui stay within large populations of non-Muslims in all parts of China, except in the North West.

\section{Discrimination and Persecution of the Hui by the Han}

In places where the Hui people are a substantial majority like in the North West of China, government officials are mostly non-Muslim Han. There is an intensified and strong enforcement of national identity on the identity of the minority Hui people. This is the second relation between the Han and the Hui. The intensification of identity of the Han towards the Hui will be paralleled and counteracted by the intensification of inner preservation of ethnic identity of the Hui. For example, the Han or the non-Muslims may take drinking wine as a national social identity of China and do it frequently in places where many Hui live. This social function is thought to bring unity to the Hui communities and reinforce their identity (Note 7).

The responses of the Hui towards the Han in this setting can be of three types: avoidance of contact with the Han, acceptance of the situation, and resistance of the Han's way. The responses can cause mutual distrust, prejudice and discrimination between the two communities. As far as contact with the Han is concerned, it is impossible to avoid as the Hui and the Han are interdependent in many social structures within the nation. If the Hui want to send their children to school for registration and other purposes, they have to contact the Han. If the Hui want to perform al-haj in Makkah, they have to apply for the passports from the government office dominated by the non-Muslim Han. The acceptance of the situation is prevalent in the first relationship mentioned above. However, when the stress of discrimination is too much and becomes intolerable, the equilibrium between the external and internal pressure is upset. Then the third relation between the Hui and the Han will happen, that is revolt or rebellion of the Hui against the Han (Note 8).

\section{Revolt of the Hui against the Han}

As a minority group, the Hui has to accept the reality of the situation. However, the discrimination against the Hui can get too intensified and the boundary of justice can be heavily infringed; this can make it highly intolerable for the Hui or Muslim communities. It may give rise to large scale revolt against the non-Muslim Han government. Several revolts or uprisings by the Hui against the Han government had occurred in the past. The most well-known of them was led by Tu Wen-Hsiu and Ping Nam-Kuo in 1856. These uprisings were reported as going against the Han government. Many of these uprisings only caused the deaths of millions of Hui Muslims (Note 9). The deaths were usually not made known to the Muslim ummah or the outside world. This is because in the $19^{\text {th }}$ century, communication like the Internet was not available at that time, beside Chinese was not a world-known language. To the Muslim Hui, the uprisings were obligatory to fight for Islam and justice and establish the Islamic system of life. However, to the Chinese government, they were barbarian revolts against the government (Note 9).

\section{The Reality of the Contemporary Setting between the Muslim Hui and the Non-Muslim Han in China}

There are about 20 million Chinese Muslim Hui in China (Note 10). However, in the past, they were separated from the rest of the Muslim ummah as they used Chinese as their main language while the ummah uses Arabic or other languages. They had also been under an isolated China in which most of them were cut off from the rest of the world. Thus, the Chinese Muslim Hui in China had been weak in their contact with the rest of the ummah. This remains even until today. This is due to several factors. First, there is serious prejudice and persecution against the Muslim Hui. Secondly, in a communist country, religion is not encouraged as religion is taken as opium by the communists. Third, the Hui could not have Islamic education. There are only a few madrasah or Islamic schools teaching Islam, fiqh and Arabic language at the very elementary level. Fourth, the Muslim Hui who want to gain high position in government ends up learning more Confucian teachings and other non-Islamic Chinese knowledge. Sometimes, they have to pass examinations based on Confucius' and Lao Tze's thoughts. For example, the late Ibrahim Ma seemed too apologetic in his book, Chinese and Islamic Thoughts. In this book, 
Ibrahim frequently compared Muhammad and Confucius and showed equal respect for both, even though Confucius was not even mentioned in Al-Quran. Books describing the weaknesses of Confucianism were frequently mentioned or quoted (Note 11) but they are not available to the Muslim ummah. Few Muslim intellects out of China know about the Chinese Muslim scholars in China. Hence, there is very little intellectual discourse or absolutely none between the Chinese Muslim scholars and other Muslim scholars out of China.

The various revolts against the non-Muslim government, including the Yunan revolt (1858-1873), were not known to the rest of the ummah, hence, there was no support from them. The Yunan revolt was at first successful and the Hui took over the state of Yunan for several years. But when the non-Muslim government attacked, millions of innocent Muslims or Hui were killed (Note 12).

In China, the Hui or Chinese Muslims only work and do jihad as isolated groups with little contact with the rest of the ummah. The revolts were frequently not reported as Islamic uprisings coming out of China. On 21 May 1999, it was reported that four Eighurs were executed for separate terrorism (Note 13). The ummah out of China were not conscious of the fact that the four were fighting for Islam and independence for their nation.

There were many Muslims or Hui in China who became known and successful in China but they did it through a very difficult struggle including having to sit for examinations based on non-Islamic syllabus. None will perceive what the legendary figure, Admiral Muhammad Cheng, had to undergo until he finally won the favour of the Emperor to lead several trips to South East Asia, to the Middle East and East Africa. Similarly, Mah Hsin-I was a Muslim Hui who became the Director General of Fukian and Chekiang amidst many great difficulties. Omar Pai was the first person to become the Minister of Defence of the Republic of China (Taiwan). But none will know the challenges he had to face when he joined the academy of army training as he was not given any Islamic dietary food. He was famous for fighting against the Japanese when Japan invaded China. He also fled to Taiwan with President Chiang Kai-Shek.

Ma Hua Loong was a leader of one of the Hui's revolts. The non-Muslims caught his mother, told him to surrender and promised not to harm him. Finally, he surrendered but he was killed. Ma Hua Loong's tomb in China is, until today, very much respected by the Hui community. There was also a very beautiful Hui woman whose body produced natural perfume. She was the wife of Khoja. In the revolt, Khoja was killed while she was taken captive and surrendered to Emperor Ching Lung. Ching Lung wanted to take her as one of his wives. She refused and said openly she would take revenge. The Emperor did not want to kill her. Instead, he offered her many wonderful things but she did not change her mind. Finally, the Queen was very afraid that she might kill the Emperor and forced her to hang herself (Note 14). All these Hui were highly remembered and respected in the Hui communities (Note 15).

\section{Social and Cultural Conflict between the Hui and the Han}

Conflicts between Muslim Hui and non-Muslim Han are normal in China. There are many reasons for this. Historically, China is one of the oldest civilizations and is ethnocentric of its history and heritage. Islam is a very young religion but it has quickly spread through the Middle East, Africa, Asian and many parts of the world. The meeting of civilization between Chinese non-Muslim Han and Muslim Hui naturally creates the three main relationships mentioned earlier. Owing to both ethnocentric feelings in their way of living, there is an uncomfortable co-existence between the two communities of Han and Hui.

As early as $206 \mathrm{BC}$ and until the $19^{\text {th }}$ century, the Han dynasty in China was called Zhong Kuo or the Middle Kingdom. People living outside the Middle Kingdom were regarded as "barbarians". The non-Muslim Han regarded themselves as superior to the "barbarians" in culture, intelligence, morality and behaviour. The relationship between the Han Chinese and the "barbarians" was likened to the feudal system of chieftain and vassals. The latter needed to admit the superiority of the former and accept acculturation unilaterally by sending tributes to the Imperial Court. In return, the vassals received presents, seals, and official titles. This confirmed the lower status of the latter. This lasted for 2000 years. The diplomatic symbolism indicated the "barbarians" subjugation to the former.

Under these kinds of condition, it is natural that today's Chinese non-Muslim Han have ethnocentric feelings of superiority compared to any other groups or tribes and refuse to accept any other way of life. In actuality, the Great Wall of China was built to prevent the uncivilized and "barbarian" tribes from invading China from the North. In order to make the "barbarians" civilized, the Chinese impose the imperial civil examination on the non-Han and Han tribes together; if the candidates pass the examination, they would be given high government positions. The syllabus for the examination consists of five classical works on Han literature and four classical texts. The candidates who study hard to pass the imperial examination usually are acculturated and assimilated into the Chinese non-Muslim Han's way. 
As far as the Hui are concerned, Islam is a complete way of life. Prophet Muhammad had succeeded in transforming a jahiliyyah or ignorant society to an enlightened way of living; from a polytheistic to a monotheistic faith, from a disorderly society with rampant alcoholism, gambling, fortune telling and womanizing to a clean society guided by Al-Shariah for the well-being of the individuals and the good of the communities. Islam has totally transformed the society into a good welfare society.

One of the significant changes brought about by the Prophet, was the eradication of the practice of rampant burying of female babies. Before the arrival of Prophet Muhammad, the Arabs during the jahilliyyah time killed their female babies for fear that they would be abused and bring shame to the family. The Arabs were later forbidden to do so when a verse from Al-Quran was revealed (Note 16). There were also frequent wars among the various tribes and quarrels over small issues. This lasted for a long time. However, Islam as an enlightened way from Allah totally altered the corrupted society and changed it into a peaceful and cohesive ummah. It also brought ihsan, love, care and brotherhood to all Muslims (Note 17).

Thus, the life of Prophet Muhammad and al-din brought by him as Al-Rasul had effectively transformed a jahilliyyah society to be a just and enlightened society and give the believers a sense of firm faith in God and practice of salih customs. The Hui community had also adopted Islam as their way of life and faith. As Islam is a comprehensive path, the Hui also like to practice the best way possible in Islam. The non-Muslim Han do not have any concept of Al-Mighty God or Al-Rasul and the Islamic way of the afterlife. They only have 5000 years of civilization with various events of history on wisdom which could be either good or bad as guidance for living. They also have Confucius and Lao Tze as great philosophers to guide them and it is natural that they are ethnocentric and view themselves better than any other tribes.

\section{The Conflict of the Burial of Omar Pei}

One of the interesting social conflicts between the Hui and the Han is the burial of the dead body of the great Muslim, Omar Pei, in Taiwan. Omar Pei was the most important Muslim in Taiwan and China before his death. Not only was he prominent among the Hui, he was also the Muslim individual most favoured by the Chinese, both in Taiwan and China. He graduated from the Paoting Military Academy. He rose to fame by participating in the army to suppress bandits in the North. He was promoted to the position of a General. In the war against the Japanese, he fought against the Japanese under Chiang Kai Sek. With Chiang Kai Sek, he was the co-ordinator of the efforts of Muslim generals in the North East against the Japanese occupation. He was instrumental in organizing the Chinese National Salvation Federation which mobilized the Hui against Japanese encroachment and acted as its President until his death. Omar Pei was appointed as the Minister of Defence in June 1946. He too was responsible for negotiation the construction and finance of the impressive New Birth Mosque. This is a great pride for the Hui people and the government (Note 18).

Omar Pei was an important figure who contributed to both the non-Muslim and Muslim communities. However, a problem occurred after his death: should he be buried according to Chinese rites or the Islamic way? The Hui said that he was a Muslim and should be buried in the Islamic way. In another opinion, it was said that he had done a lot for the nation; therefore, it should be allowed to let the people pay homage to him befitting a person of his stature. Normally, a Muslim funeral must be done within three days. The corpse must be washed properly, wrapped up in white shroud and after being prayed for, would be buried without a coffin whereas in the non-Muslim tradition, the Han's way, the corpse needs to be kept at home in a costly coffin (to indicate the position of the dead person) for people to pay their last respects. According to some writers, only a person of no position and in a very poor situation would there be no coffin for the corpse. This would be taken as disrespect to the ancestors of the family.

In the Chinese non-Muslim Han's tradition, there was a stereotype that the Hui were stingy and so refused to use a coffin. They also accused the Hui for using the "the (same) coffin" again and again in the mosque. The Chinese non-Muslim Han would generally spend a big amount of money for a costly coffin upon death. Furthermore, they said that the burial day should be determined by a Feng Shui expert or it could influence the prosperity of the next generation of the deceased. This is haram in Islam. Besides, burning of incense, loud wailing, mourning and inviting a monk or Taoist to do any reading or any chanting are all forbidden in Islam.

The problem was Omar Pei did not make any will regarding his funeral. If he had specified his funeral, it would happen according to his will. However, like any Hui, he did not make any will for his own funeral. It was assumed that he was a Muslim and his funeral would be done according to the Islamic rites. Besides, in Islam, the management of the burial of a Muslim is a joint responsibility of all Muslims. Failure to do so is a sin to the whole Muslim community (Note 19). 
The story started when Omar Pei was struck by a heart attack on a Friday and consequently, died. At his deathbed was Sulaiman, an assemblyman and a national committee member of the Old Oxen Mosque and Director of the Chinese Muslim Association. Musa, Chairman of the Board of New Birth Mosque was also there. He called a meeting to decide who to bathe the corpse, to wrap it up in white shroud, to pray janaza and do the prayers (Note 20).

In the meeting, Sulaiman proposed that the Islamic way should be applied to prepare the body for burial and later, it was to be sent to the Taipei Municipal Parlour for public viewing. Idris and General Sa were not in favour of public viewing. It was the Han's funeral parlour. The meeting was postponed to the next day. However, the Han government also sent its people. The funeral committee was formed with both the Hui and the Han. In a meeting the next day, President Chiang Kai-shek sent his representatives and proposed a non-Islamic funeral rite.

This was opposed by Idris and General Sa. The Chairman revised his decision and finally agreed to an Islamic funeral and after the burial, a separate commemorative ceremony was to be set up (Note 20). It was agreed that Omar Pei should be buried according to Islamic rites but the body must be put at the Taipei Municipal Parlour for public viewing. The body of the late Omar Pei was therefore placed in the location. He was there for a week. The white shroud which wrapped the body in the mosque after he had been bathed was in fact removed. In Han's way, Pai's face was shaved and made up with cosmetics. There he was redressed with very fine clothes with a little hat like those worn by the non-Muslim Han. The non-Muslim Han began to kowtow and bow to the corpse to show their respect. Fruit and flowers were offered to the corpse besides candles and incense burnt to 'worship' it (Note 20).

The Hui were so infuriated by what had happened at the Taipei Municipal Parlour that Musa did not attend the ceremony for the final burial of Omar Pei. General Sa protested vehemently but could not do anything. Many Hui were very angry with Sulaiman for his idea to put the body of Omar Pei at the Taipei Municipal Parlour. The Hui started to quarrel among themselves because of this. It was only after some time that they forgot about this event (Note 20).

Omar Pei was finally buried according to the Islamic way. The government of ROC Taiwan also spent millions of Taipei Yen to build a very beautiful place near the tomb to remember his contributions to the nation. Many tourists visit the tomb of the first Defence Minister of ROC Taiwan. Few could have known about the events that led to the body of Omar Pei being placed in the parlour for public viewing for a week.

\section{Conclusion}

The Hui are numerically a large number of people in China of about 20 millions. However, the Han are far larger and the official figure is 1.3 billion. With political hegemony and cultural differences between the Han and the Hui, it is natural that the minority Hui face a lot of issues in such environments in their interaction and integration with the Han in China.

It is unlikely that the Chinese Muslim Hui will emerge as a strong ethnic group in China in the near future. Because of the national educational policy in which Islam has not been included as a part of the syllabus, the Chinese Muslim Hui would not know much about Islam like the non-Muslims. In fact, they learn more about the non-Muslim way than the Islamic ways. Furthermore, anyone joining the police, army or any governmental institute of training will not be catered with Islamic practices like halal food; most food provided is frequently non-halal. To join the ranks of government officials, one has to pass the examination which does not have Islamic contents. Many schools also do not provide Islamic teachings. There is a tendency for the Chinese Muslim Hui to be acculturated and assimilated into the non-Muslim Han way.

Since the Hui belong to a relatively small group compared to the Han, the fear of the Hui as an ethnic group is the assimilation into the Han's way of life. If any Hui wants to be successful politically, he has to toe the way of the Han's and accommodate himself to the mainstream of political and cultural forces in China. A prominent national figure must join the Chinese Communist Party to climb the political ladder. For instance, Rashid Pau, the National Honorary President of Chinese Muslim Association, the sixth Vice-Chairman of the National Political Co-ordination Committee in China, was a very prominent communist member. He had to struggle to the tune of the Communist Chinese policies such as accommodating to the socialist system of government his whole life and respecting the integrity of the Chinese government to achieve the honourable position; for that he was respected by non-Muslim national figures. He passed away on August 27, 1989 (Note 21).

Similarly, in Taiwan, Omar Pei, the first Minister of ROC Taiwan had to toe the line of the Nationalist government of President Chiang Kai-Shik or he would not have risen to the position of Defence Minister. The national policy of China to assimilate the Muslim Hui had been successful except in the North West part of 
China. The official figure of Chinese Muslims according to the census is not more than 21 millions. However, two known writers had written that the Muslims in China were 50 and 40 millions in 1974 and 1990 respectively.

\section{References}

Al-Umari, A. D. (1992). Madinan Society at the Time of the Prophet. Washington D.C. Institute of Islamic Thought.

Chang, Y. (n.d.). The Muslims in China. The Muslim World League Journal, 17.

Chuah, O. A. (2004, April). Muslims in China: The Social and Political Situation of the Hui Chinese. Journal of Minority Muslim Affairs, 24(1).

Fei Hsiao-tung. (1968). China Gentry. Chicago, University of Chicago.

Hsu, F. L. K. (1969). Under the Ancestor's shadow: Kinship, Personality, and Social Mobility in Village China. Garden City, Double Anchor, Taiwan.

Israel, R. (1974). Chinese versus Muslims: A Study of Cultural Confrontation, unpublished Ph. D. Thesis, University of California.

Ma, I. (1960). Muslims in China. Kuala Lumpur, PERKIM.

Ma, I. (1991). Chinese and Islamic Thoughts. Brunei Darul Salam, Islamic Da'wah Center of Brunei.

Pillsbury, B. L. K. (1973). Cohesion and Cleavage in a Chinese Muslim minority, unpublished PhD Thesis, Columbia University.

Simpson, G. E., \& Yinger, J. M. (1987). Racial and Cultural Minorities. New York, Plenum.

Tsai, Y. L. (1997). Confucian Orthodoxy vs Muslim Resistance, unpublished PhD thesis, Temple University.

Yuen, K. W., \& Li, H. C. P. (1969). The Funeral of a Muslim. Taiwan.

\section{Notes}

Note 1. The Chinese Muslim scholar was invited by the Malaysian government to explain about Islam to non-Muslims. I met him at the Baitu al-Mal Building, Kuala Lumpur when I did a deep research on Chinese Muslims in Malaysia.

Note 2. http://www.savetibet.org/resource-center/maps-data-fact-sheets/self-immolation-fact-sheet.

Note 3. Survey is done among Hui students doing undergraduate studies in Malaysia.

Note 4. Simpson G.E. and Yinger, J.M. Op.cit., p.9.

Note 5. http://muslimvillage.com/2011/08/06/12867/chinese-muslims-banned-from-fasting-in-ramadan/

Note 6. Raphael Israel, Op.cit., pp. x-xii.

Note 7. Osman Abdullah Chuah, Op.cit., p. 157.

Note 8. Raphael Israel, Op.cit., pp. xii-xiii.

Note 9. Pai Shui-I, Hui-min Chi-I (The Righteous Uprising of Muslim Nationality), 4 Vol. Peking, 1953; Wang Shu-huai, Hsien T'ung Yunan Hui Min shih-luan, (The Muslim Uprising in Yunnan 1856-1873), Taipei, 1968.

Note 10. Population Census of China 2000.

Note 11. Wang Tai Yu, Ching Cheng Chen Chuan, Explanation of the true religion, 1967.

Note 12. Pai Shu-i, Op.cit, and Wang Shu-huai, Op.cit.

Note 13. The News Straits Times, 21 May 1999. p. 16.

Note 14. Pai Shui-I Op.cit; Ibrahim Ma.

Note 15. Ibrahim Ma, Op.cit., p.72.

Note 16. Quran 6: 151.... kill not your babies.

Note 17. Akram Diya Al-Umari, Op.cit.

Note 18. Pillsbury, Barbara Linne Kroll, 1973, Op.cit., p. 187.

Note 19. `Abdur Rahman I Doi, Shari ah the Islamic Law Kuala Lumpur, A.S. Noordeen. 1989.

Note 20. Pillsbury, Barbara Linne Kroll, Op.cit.

Note 21. The Chinese Muslims (Al-Muslim Al-Shini,) No 6, Peking, Chinese Muslim Association 1989. pp.2-23. 